\title{
A Comparative Study between the Efficacy of Ritodrine Hydrochloride Versus Nitroglycerin Patch as a Short Term Tocolysis
}

\author{
GEHAD A.A. EL-SADANY, M.Sc.; SHREEN B. EL-BOHOTY, M.D.; AMAL E. MAHFOUZ, M.D. and \\ MOHAMED E. ABDO, M.D.
}

The Department of Obstetrics and Gynecology, Faculty of Medicine, Tanta University

\begin{abstract}
Background: Preterm birth continues to be a problem for obstetricians. Preterm birth complicates $8-10 \%$ of birth. Although the causes of preterm labour are not well understood, the burden of preterm birth is clear. The majority of neonatal deaths and over one third of infant deaths are linked to preterm birth. Methods to detect preterm labour at early stage include ultrasound examination of cervix and detection of biochemical markers of preterm labour in blood, saliva and cervicovaginal secretion. Given the methods to predict and prevent preterm birth are imperfect, attention focuses on the treatment of women admitted with preterm labour.
\end{abstract}

Aim of the Work: The aim of the study to compare the safety and efficacy of transdermal nitroglycerine patch versus ritodrine hydrochloride in treatment preterm labour.

Patients and Methods: This retrospective study was included 50 cases of threatened preterm labour attending the Obstetrics and Gynecology Department of Tanta University Hospital who were involved in this study. Woman were randomly divided in this retrospective study into two groups: Group 1: Included twenty five (25) patient, they received Bsympathomimetc ritodrine (yutopar). Ritodrine was giving in dose of: $150 \mathrm{mg}$ in $500 \mathrm{ml}$ saline infusion starting dose is $0.05 \mathrm{mg} / \mathrm{min}$ this to be increased $0.05 \mathrm{mg} / \mathrm{min}$ every $10-15$ minutes $(1 \mathrm{ml}$ contain $0.3 \mathrm{mg}$ and $1 \mathrm{ml}$ about 16 drops so $0.05 \mathrm{mg}$ about 3 drops) until a dose that provide tocolytic effect is reached or maternal tachycardia above 130 beats/minute occur. Group 2: Included twenty five (25) patients treated with $10 \mathrm{mg}$ nitrodermal patch directly applied on the abdominal skin.

Inclusion Criteria: Pregnant woman in the age of 20-35 years, gestational age between $28-34$ weeks, body mass index (25-30), singleton pregnancy, uterine contraction 2 per 10 minutes or 4 per 20 minutes, cervical dilatation 3 centimeters, effacement up to $80 \%$, intact membranes and primigravida or multigravida.

Exclusion Criteria: Fetal problems: Fetal congenital anomalies, fetal growth restriction and fetal distress. Maternal problems: "Medical problems": Chronic hypertension, chronic renal disease, cardiac disease, diabetes mellitus, contraindication to beta agonists, non-steroidal anti-inflammatory drugs

Correspondence to: Dr. Gehad A.A. El-Sadany, The Department of Obstetrics and Gynecology, Faculty of Medicine, Tanta University and other tocolytics, cigarette smoker, anemia (HB less than $10 \mathrm{mg} / \mathrm{dl}$ ), thyroid disorders, maternal tachycardia ."Obstetric problems": Preeclampsia, polyhydraminos and oligohydraminos, ante-partum hemorrhage and rupture of membranes and Chorioamnionitis. All patients were subjected to thorough history taking with special emphasis on gestational age (in weeks), history of medical disease) and clinical examination regarding blood pressure and body mass index. Obstetrical abdominal ultrasound was done for gestational age (BPD, AC, FL), amniotic fluid, viability. Routine investigations as fasting blood sugar blood group and $\mathrm{Rh}$ factor, blood urea, creatinine, haemoglobin concentration and analysis of urine albumin, sugar, microscopy, culture and sensitivity.

Results: Equal percentage in cases which delivered in the same day and not responding to the drugs only 2 cases in each group present $8.0 \%$. In the next day 3 cases delivered in group 1 present $12.0 \%$ and 1 case in group 2 present $4.0 \%$. The delivery in the first 48 hours present failure rate of the drug, in our study the failure rate was $20 \%$ in group 1 and $12 \%$ in group 2. Labour by 7 day occur in 2 cases in each group presenting $8.0 \%$ in each group. Labour by 14 day occurred in 2 cases in group 1 and 1 case in group 2 presenting $8 \%$ and $4 \%$ respectively. Labour at 32 week occurred in 3 cases in group 1 and 2 cases in group 2 presenting $12 \%$ and $8 \%$ respectively. Labour at 34 week occurred in 4 cases in each group presenting $16 \%$ to each group. Labour at 37 week occurred in 6 cases in group 1 and 8 cases in group 2 presenting $24 \%$ and $32 \%$ respectively. Labour by 32 week occurred in 6 cases in group 1 and 2 cases in group 2 presenting 24 and 8 respectively. Labour by 34 week occurred in 2 cases in group 1 and 3 cases in group 2 presenting $8 \%$ and $12 \%$ respectively. Labour by 37 week occurred in 4 cases in group 1 and 6 cases in group 2 presenting $16 \%$ and $24 \%$.

Conclusion: Both glyceryltrinitrate and ritodrine were comparable in prolongation of gestation in patients in preterm labour, both in duration and in terms of success. The advantages of glyceryltrinitrate patch over ritodrine are lesser side effects and simplicity of administration and it also allows the patient to remain ambulatory.

Key Words: Nitroglycerine - Ritodrine - Preterm labour.

\section{Introduction}

PRE-TERM labour is defined as the onset of labour after the age of viability (20-24) and before 
37 completed weeks of pregnancy and its incidence is $6-10 \%$ of all births in developed countries [1] It is common in patients with low body weight, low stature, smokers and lower social classes [2] Risk factors that have been linked to pre-term delivery include cervical incompetence, haemorrhage like abruptio placenta, genital tract infection like bacterial vaginosis, hormonal changes due to maternal or foetal stress, multifoetal pregnancy and previous history of pre-term labour [3]. Complications of prematurity account for more than $70 \%$ of foetal and neonatal deaths annually in babies without anomalies [4]. The treatment includes bed rest, hydration and sedation, the measures that are commonly used are tocolytic drugs, corticosteroids and antibiotics. Tocolytics are pharmacological agents that relax the uterine myometrium and inhibit uterine contractions leading to abolition of preterm labour. They act through a variety of mechanisms to decrease the availability of intracellular calcium ions leading to inhibition of actin-myosin interaction. Though, use of tocolytic drugs has become controversial, they should still be considered if the few days gained would be put to good use such as completing a course of corticosteroids or in-utero transfer [5] . They are not recommended after 34 weeks gestation and currently there is no consensus regarding the lower gestational limit at which they could be used [6] Many tocolytic drugs have been developed and used and several experimental drugs are being evaluated. Beta sympathomimetics, calcium channel blockers, magnesium sulphate, oxytocin antagonists, prostaglandin synthetase inhibitors, nitric oxide and combination of these drugs have been used for tocolysis [5]. Future research is needed for development of drugs with more utero selectivity and fewer side effects. Recently, nitric oxide donors have been found to be potent uterine relaxants in vitro and transdermal nitroglycerine has been reported to be safe for the mother and the fetus [7]. Nitroglycerine (nitric oxide donors) may be an-effective choice as a tocolytic agent due to its safety profile with infrequent maternal and foetal side effects [7].

\section{Aim of the work:}

The aim of the study to compare the safety and efficacy of transdermal nitroglycerine patch versus ritodrine hydrochloride in treatment preterm labour.

\section{Patients and Methods}

This retrospective study included 50 case of threatened preterm labour attending the Obstetrics and Gynecology Department of Tanta University Hospital involved in this study.
Inclusion criteria: Pregnant woman in the age of 20-35 years, gestational age between 28-34 weeks, body mass index (25-30), singleton pregnancy, uterine contraction 2 per 10 minutes or 4 per 20 minutes, cervical dilatation 3 centimeters, effacement up to $80 \%$, intact membranes and primigravida or multigravida.

Exclusion criteria: Fetal problems: Fetal congenital anomalies, fetal growth restriction and fetal distress.

Maternal problems: "Medical problems": Chronic hypertension, chronic renal disease, cardiac disease, diabetes mellitus, contraindication to beta agonists, non-steroidal anti-inflammatory drugs and other tocolytics, cigarette smoker, anemia (HB less than $10 \mathrm{mg} / \mathrm{dl}$ ), thyroid disorders, maternal tachycardia. "Obstetric problems": Preeclampsia, polyhydraminos and oligohydraminos, ante-partum hemorrhage and rupture of membranes and chorioamnionitis. All patients were subjected to thorough history taking with special emphasis on gestational age (in weeks), history of medical disease and clinical examination regarding blood pressure and body mass index. Obstetrical abdominal ultrasound was done for gestational age (BPD, AC, FL), amniotic fluid, viability. Routine investigations as fasting blood sugar blood group and $\mathrm{Rh}$ factor, blood urea, creatinine, haemoglobin concentration and analysis of urine albumin, sugar, microscopy, culture and sensitivity.

Woman were randomly divided in this prospective study into two groups: Group 1: Includes twenty five (25) patient, they received Bsympathomimetc ritodrine (yutopar). Ritodrine was giving in dose of: $150 \mathrm{mg}$ in $500 \mathrm{ml}$ saline infusion starting dose is $0.05 \mathrm{mg} / \mathrm{min}$ this to be increased $0.05 \mathrm{mg} / \mathrm{min}$ every $10-15$ minutes $(1 \mathrm{ml}$ contain $0.3 \mathrm{mg}$ and $1 \mathrm{ml}$ about 16 drops so $0.05 \mathrm{mg}$ about 3 drops) until a dose that provide tocolytic effect is reached or maternal tachycardia above 130 beats/minute occur. Group 2: Includes twenty five (25) patients treated with $10 \mathrm{mg}$ nitrodermal patch directly applied on the abdominal skin. If after one hour no reduction of uterine contractions, an additional patch can be applied (10mg) at the same time for 24 hours. All patient will received 3 doses $8 \mathrm{mg} / 8$ hours dexamethasone intramuscular.

\section{Results}

There was no statistical significant differences between the two studied groups according to age, BMI, parity, previous preterm labour, uterine contraction, cervical dilatation, gestational age on admission and gestational age on delivery. Also 
when compare the 2 studied group it was found there was no statistical significant differences between the two studied groups according to fetal weight.

Table (1): Changes in maternal Heart Rate (HR) in both group before treatment and after $15 \mathrm{~m}, 30 \mathrm{~m}, 1 \mathrm{~h}, 6 \mathrm{~h}, 12 \mathrm{~h}$ and $24 \mathrm{~h}$ after treatment.

\begin{tabular}{ccccc}
\hline HR (in min) & Range & Mean \pm SD & $t$-test & $p$-value \\
\hline On admission: & & & & \\
Group 1 & $68-88$ & $77.32 \pm 6.12$ & 0.026 & 0.873 \\
Group 2 & $68-90$ & $77.04 \pm 6.16$ & & \\
After 15m: & & & & \\
$\quad$ Group 1 & $72-96$ & $83.88 \pm 6.43$ & 9.419 & $0.004^{*}$ \\
Group 2 & $70-92$ & $78.56 \pm 5.81$ & & \\
After 30m: & & & & \\
Group 1 & $78-96$ & $88.72 \pm 5.41$ & 28.360 & $0.001 *$ \\
Group 2 & $72-92$ & $80.04 \pm 6.09$ & & \\
After 1 h: & & & & \\
Group 1 & $80-100$ & $92.32 \pm 4.64$ & 55.737 & $0.001 *$ \\
Group 2 & $72-92$ & $81.00 \pm 5.99$ & & \\
After 6h: & & & & \\
Group 1 & $84-102$ & $95.04 \pm 4.17$ & 96.242 & $0.001 *$ \\
Group 2 & $73-94$ & $81.04 \pm 5.79$ & & \\
After 12h: & & & & \\
Group 1 & $82-102$ & $95.76 \pm 4.05$ & 89.762 & $0.001 *$ \\
Group 2 & $73-96$ & $83.04 \pm 5.35$ & & \\
After 24h: & & & & \\
Group 1 & $84-102$ & $96.48 \pm 3.38$ & 85.597 & $0.001 *$ \\
Group 2 & $78-94$ & $85.28 \pm 5.02$ & & \\
\hline -value >0.050 non significant. & & & \\
$p$-value <0.050 significant*. & & & \\
\hline
\end{tabular}

This table show: Group (1): On admission maternal heart rate ranged between $68-88$, after giving the drug (Ritodrine) our study show there was increase in MHR.

As by estimation MHR after $15 \mathrm{~min}$ it was ranged between $72-96 / \mathrm{min}$, then after 30min ranged between $78-96 / \mathrm{min}$, then after $1 \mathrm{~h}$ ranged between $80-100 / \mathrm{min}$, then after $6 \mathrm{~h}$ ranged between $84-$ $102 / \mathrm{min}$, then after $12 \mathrm{~h}$ ranged between $82-102 / \mathrm{min}$ and after $24 \mathrm{~h}$ ranged between $84-102 / \mathrm{min}$. So this values show gradual increase which became statistically significant after $15 \mathrm{~min}$.

Group (2): On admission maternal heart rate ranged between 68-90, after giving the drug $(\mathrm{Ni}-$ troglycerine) our study show there was increase in MHR after $1 \mathrm{~h}$.

As by estimation MHR after $15 \mathrm{~min}$ it was ranged between $70-92 / \mathrm{min}$, then after 30min ranged between $72-92 / \mathrm{min}$, then after $1 \mathrm{~h}$ ranged between $72-92$, then after $6 \mathrm{~h}$ ranged between 73-94/min, then after $12 \mathrm{~h}$ ranged between $73-96 / \mathrm{min}$ and after
$24 \mathrm{~h}$ ranged between $78-94 / \mathrm{min}$. So this values show gradual increase in MHR which became statistically significant after $1 \mathrm{~h}$.

Conclusion: When compare the 2 studied group it was found MHR after treatment was significant higher in group 1 than group 2. (Table 1).

Table (2): Changes in Mean Arterial Pressure (MAP) mmHg before treatment and after $15 \mathrm{~m}, 30 \mathrm{~m}, 1 \mathrm{~h}, 6 \mathrm{~h}, 12 \mathrm{~h}$ and $24 \mathrm{~h}$ after treatment.

\begin{tabular}{lllll}
\hline $\begin{array}{l}\text { Mean arterial } \\
\text { pressure (mmHg) }\end{array}$ & Range & Mean \pm SD & $t$-test & $p$-value \\
\hline $\begin{array}{l}\text { On admission: } \\
\text { Group 1 }\end{array}$ & $76-110$ & $95.16 \pm 8.71$ & 1.154 & 0.288 \\
Group 2 & $73-116$ & $92.08 \pm 11.39$ & & \\
After 15m: & & & & \\
$\quad$ Group 1 & $73-106$ & $90.44 \pm 8.08$ & 0.012 & 0.988 \\
Group 2 & $70-112$ & $90.48 \pm 10.72$ & & \\
After 30m: & & & & \\
Group 1 & $71-102$ & $88.04 \pm 8.27$ & 0.429 & 0.516 \\
Group 2 & $72-110$ & $89.80 \pm 10.59$ & & \\
After 1h: & & & & \\
Group 1 & $72-100$ & $86.16 \pm 7.98$ & 1.073 & 0.305 \\
Group 2 & $70-110$ & $88.96 \pm 10.91$ & & \\
After 6h: & & & & \\
Group 1 & $70-99$ & $83.84 \pm 8.05$ & 1.671 & 0.202 \\
Group 2 & $70-106$ & $87.12 \pm 9.81$ & & \\
After 12h: & & & & \\
$\quad$ Group 1 & $70-97$ & $83.00 \pm 7.76$ & 1.217 & 0.275 \\
Group 2 & $70-106$ & $85.80 \pm 10.05$ & & \\
After 24h: & & & & \\
Group 1 & $70-95$ & $82.04 \pm 7.26$ & 1.512 & 0.225 \\
Group 2 & $70-100$ & $85.04 \pm 9.80$ & & \\
\hline & & & &
\end{tabular}

This table show: Group (1): On admission the mean arterial blood pressure (MAP) ranged between 76-110, after giving the drug (Ritodrine) our study show there was decrease in MAP after $15 \mathrm{~min}$.

As by estimation MAP after $15 \mathrm{~min}$ it was ranged between $73-106 \mathrm{mmHg}$, then after $30 \mathrm{~min}$ ranged between $71-102 \mathrm{mmHg}$, then after $1 \mathrm{~h}$ ranged between $72-100 \mathrm{mmHg}$, then after $6 \mathrm{~h}$ ranged between $70-99 \mathrm{mmHg}$, then after $12 \mathrm{~h}$ ranged between $70-97 \mathrm{mmHg}$ and after $24 \mathrm{~h}$ ranged between $70-95$ $\mathrm{mmHg}$. So this values show gradual decrease in MAP which became statistically significant after $15 \mathrm{~min}$.

Group (2): On admission the mean arterial blood pressure (MAP) ranged between 73-116 $\mathrm{mmHg}$, after giving the drug (Nitroglycerine) our study show there was decrease in MAP after $12 \mathrm{~h}$.

As by estimation MAP after $15 \mathrm{~min}$ it was ranged between $70-112 \mathrm{mmHg}$, then after $30 \mathrm{~min}$ 
ranged between $72-110 \mathrm{mmHg}$, then after $1 \mathrm{~h}$ ranged between $70-110 \mathrm{mmHg}$, then after $6 \mathrm{~h}$ ranged between $70-106 \mathrm{mmHg}$, then after $12 \mathrm{~h}$ ranged between $70-106 \mathrm{mmHg}$ and after $24 \mathrm{~h}$ ranged between $70-$ $100 \mathrm{mmHg}$. So this values show decrease in MAP which became statistically significant after $12 \mathrm{~h}$.

Conclusion: When compare the 2 studied group it was found there was no significant statistical difference between two studied groups (Table 2).

Table (3): Changes in Fetal Heart Rate (FHR) before treatment and after $15 \mathrm{~m}, 30 \mathrm{~m}, 1 \mathrm{~h}, 6 \mathrm{~h}, 12 \mathrm{~h}$ and $24 \mathrm{~h}$ after treatment.

\begin{tabular}{ccccc}
\hline FHR (min) & Range & Mean \pm SD & $t$-test & $p$-value \\
\hline $\begin{array}{c}\text { On admission: } \\
\text { Group 1 }\end{array}$ & $126-150$ & $138.12 \pm 7.18$ & 0.114 & 0.737 \\
Group 2 & $125-150$ & $137.44 \pm 7.08$ & & \\
After 15m: & & & & \\
$\quad$ Group 1 & $130-152$ & $141.08 \pm 6.61$ & 2.054 & 0.158 \\
Group 2 & $126-150$ & $138.36 \pm 6.81$ & & \\
After 30m: & & & & \\
$\quad$ Group 1 & $132-154$ & $144.16 \pm 6.32$ & 6.154 & $0.017^{*}$ \\
Group 2 & $128-150$ & $139.68 \pm 6.45$ & & \\
After 1 h: & & & & \\
$\quad$ Group 1 & $136-155$ & $146.68 \pm 5.57$ & 11.579 & $0.001^{*}$ \\
Group 2 & $128-152$ & $140.76 \pm 6.69$ & & \\
After 6h: & & & & \\
Group 1 & $140-157$ & $149.64 \pm 4.79$ & 21.128 & $0.001^{*}$ \\
Group 2 & $130-154$ & $141.64 \pm 7.27$ & & \\
After 12h: & & & & \\
$\quad$ Group 1 & $142-158$ & $151.76 \pm 4.66$ & 24.787 & $0.001^{*}$ \\
Group 2 & $132-156$ & $143.24 \pm 7.18$ & & \\
After 24h: & & & & \\
Group 1 & $148-160$ & $153.88 \pm 3.93$ & 38.228 & $0.001^{*}$ \\
Group 2 & $132-156$ & $143.60 \pm 7.33$ & & \\
\hline & & & &
\end{tabular}

This table show: On admission the FHR ranged between 126-1 50\Min, after giving the drug (Ritodrine) our study show there was increase in FHR after 30min.

As by estimation FHR after $15 \mathrm{~min}$ it was ranged between $130-152 / \mathrm{min}$, then after 30min ranged between $132-154 / \mathrm{min}$, then after $1 \mathrm{~h}$ ranged between $136-155 / \mathrm{min}$, then after $6 \mathrm{~h}$ ranged between 140 $157 /$ min, then after $12 \mathrm{~h}$ ranged between 142-158/ min and after $24 \mathrm{~h}$ ranged between $148-160 / \mathrm{min}$. So this values show gradual increase in FHR which became statistically significant after 30min.

Group (2): On admission the FHR ranged between 125-150/min, after giving the drug (Nitroglycerine) our study show there was increase in FHR after $1 h$.
As by estimation FHR after 15 min it was ranged between $126-150 / \mathrm{min}$, then after 30min ranged between $128-150 / \mathrm{min}$, then after $1 \mathrm{~h}$ ranged between $128-152 / \mathrm{min}$, then after $6 \mathrm{~h}$ ranged between 130 $154 \mathrm{~min}$, then after $12 \mathrm{~h}$ ranged between 132-156/ $\mathrm{min}$ and after $24 \mathrm{~h}$ ranged between 132-156/min. So this values show gradual increase in FHR which became statistically significant after $1 \mathrm{~h}$.

Conclusion: When compare the 2 studied group it was found FHR after treatment was significant higher in group 1 over course of treatment than group 2 (Table 3 ).

Table (4): Fate of the drug in both groups according to onset of labour.

\begin{tabular}{|c|c|c|c|c|}
\hline Delivery & Group 1 & Group 2 & $\chi^{2}$ & $p$-value \\
\hline \multicolumn{5}{|c|}{ In same day: } \\
\hline $\mathrm{N}$ & 2 & 2 & 0.0 & 1.0 \\
\hline$\%$ & $8.0 \%$ & $8.0 \%$ & & \\
\hline \multicolumn{5}{|c|}{ In next day: } \\
\hline $\mathrm{N}$ & 3 & 1 & 1.087 & 0.297 \\
\hline$\%$ & $12.0 \%$ & $4.0 \%$ & & \\
\hline \multicolumn{5}{|l|}{ By $7 D$ : } \\
\hline $\mathrm{N}$ & 2 & 2 & 0.0 & 1.0 \\
\hline$\%$ & $8.0 \%$ & $8.0 \%$ & & \\
\hline \multicolumn{5}{|l|}{ By 14D: } \\
\hline $\mathrm{N}$ & 2 & 1 & 0.355 & 0.552 \\
\hline$\%$ & $8.0 \%$ & $4.0 \%$ & & \\
\hline \multicolumn{5}{|l|}{ At $32 W:$} \\
\hline $\mathrm{N}$ & 3 & 2 & 0.222 & 0.637 \\
\hline$\%$ & $12.0 \%$ & $8.0 \%$ & & \\
\hline \multicolumn{5}{|l|}{ At $34 W:$} \\
\hline $\mathrm{N}$ & 4 & 4 & 0.0 & 1.0 \\
\hline$\%$ & $16.0 \%$ & $16.0 \%$ & & \\
\hline \multicolumn{5}{|l|}{ At $37 W:$} \\
\hline $\mathrm{N}$ & 6 & 8 & 0.397 & 0.529 \\
\hline$\%$ & $24.0 \%$ & $32.0 \%$ & & \\
\hline \multicolumn{5}{|l|}{ By $32 W:$} \\
\hline $\mathrm{N}$ & 6 & 2 & 2.381 & 0.123 \\
\hline$\%$ & $24.0 \%$ & $8.0 \%$ & & \\
\hline \multicolumn{5}{|l|}{ By $34 W$ : } \\
\hline $\mathrm{N}$ & 2 & 3 & 0.222 & 0.637 \\
\hline$\%$ & $8.0 \%$ & $12.0 \%$ & & \\
\hline \multicolumn{5}{|l|}{ By $37 W$ : } \\
\hline $\mathrm{N}$ & 4 & 6 & 0.501 & 0.480 \\
\hline$\%$ & $16.0 \%$ & $24.0 \%$ & & \\
\hline
\end{tabular}

This table show: Equal percentage in cases which delivered in the same day and not responding to the drugs only 2 cases in each group present $8.0 \%$. In the next day 3 cases delivered in group 1 present $12.0 \%$ and 1 case in group 2 present $4.0 \%$. The delivery in the first 48 hours present 
failure rate of the drug, in our study the failure rate was $20 \%$ in group 1 and $12 \%$ in group 2 . Labour by 7 day occur in 2 cases in each group presenting $8.0 \%$ in each group. Labour by 14 day occurred in 2 cases in group 1 and 1 case in group 2 presenting $8 \%$ and $4 \%$ respectively. Labour at 32 week occurred in 3 cases in group 1 and 2 cases in group 2 presenting $12 \%$ and $8 \%$ respectively. Labour at 34 week occurred in 4 cases in each group presenting $16 \%$ to each group. Labour at 37 week occurred in 6 cases in group 1 and 8 cases in group 2 presenting $24 \%$ and $32 \%$ respectively. Labour by 32 week occurred in 6 cases in group 1 and 2 cases in group 2 presenting 24 and 8 respectively. Labour by 34 week occurred in 2 cases in group 1 and 3 cases in group 2 presenting $8 \%$ and $12 \%$ respectively. Labour by 37 week occurred in 4 cases in group 1 and 6 cases in group 2 presenting $16 \%$ and $24 \%$.

Conclusion: By comparing the two studed group there was no significant statistically difference between the both groups (Table 4) \& Fig. (1).

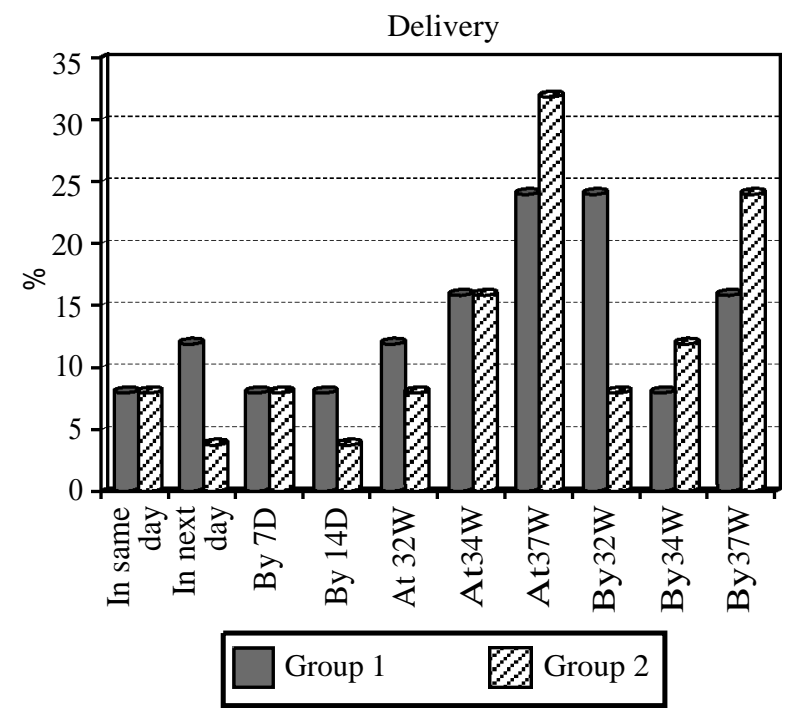

Fig. (1): There was no significant statistically difference between the both groups according to the gestational age in delivary.

When compare the 2 studied group it was found that group 1 showed significantly higher percentage of cases suffering from palpitation, tachycardia and chest pain than group 2 . Group 2 showed significantly higher percentage of cases suffering from headache than group 1 . When compare the 2 studied group it was found there was no statistical significant differences between the two studied groups in fetal side effect Fig. (2).

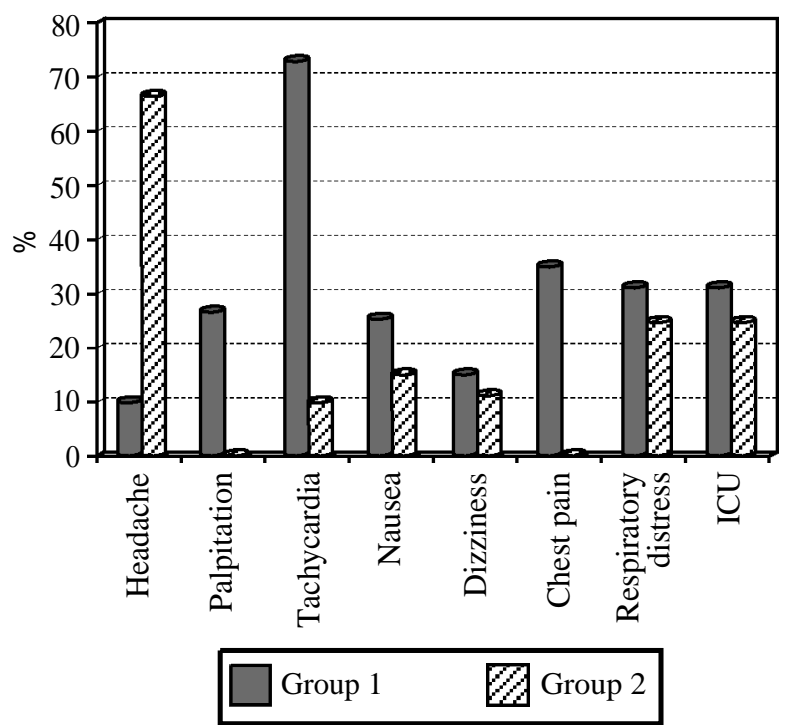

Fig. (2): There was no statistical significant differences between the two studied groups according to fetal weight.

\section{Discussion}

Preterm labour is characterized by observable uterine contractions of at least one every 10 minutes of sufficient magnitude to effect progressive cervical dilatation up to $2 \mathrm{~cm}$, cervical length less than $1 \mathrm{~cm}$ or rupture of membranes. Intervention with tocolytics remain a dilemma, due to non-availability of a wide spectrum of pharmacological agents [8] Existing drugs have relatively short duration of action, lack utero-specificity, have poor efficacy and are often associated with potentially serious maternal and fetal adverse effects. Tocolytics delay PTL long enough for corticosteroids to induce fetal lung maturation or allow mother's transportation to a tertiary care centre but they have not been shown to greatly improve neonatal outcomes [8]

In the present study we aimed to compare the safety and efficacy of transdermal nitroglycerine patch versus ritodrine hydrochloride in treatment of preterm labour we included 50 patients with threatened preterm labour were divided into two group group 1 received ritodrine hydrochloride and 2 received nitroglycerin patch.

In the current study we found that there was no statistical significant differences between the two studied groups as regard age, parity, BMI, previous preterm labour, cervical dilatation, uterine contractions, gestational age on admission and gestational age on delivery.

In agree with our study a RCT by Jain C et al., [8] comparing the Glyceryl trinitrate patch versus intravenous ritodrine for tocolysis in pre-term 
labour they found that The mean age of both groups were comparable at 23.72 in group I and 23.88 in group II, $48 \%$ in both groups were nulliparous with no statistical difference between both the groups regarding parity. No statistical significance was noted amongst the two groups with respect to history of previous abortions and preterm deliveries [8].

As regard to Singh N et al., study comprised of a total of 200 cases of preterm labour. Out of these, 60 patients were treated with ritodrine, 50 with isoxsuprine, 30 with nifedepine, 30 with glyceryltrinitrate and 30 with magnesium sulphate showed no significant differences between studied groups and demographic data and this agree with our result [9]. In RCT by Jain C et the difference was not statistically significant $(p=0.07)$ and this in consistent with our result.

Counter with our study they disagree with our study in that they showed that the mean gestational age at delivery was 34.97 in GTN group as compared to 33.24 weeks in Ritodrine group which is statistically significant $(p=0.0004)$ [8] .

In agreement with our result Smith GN et al., study found that there was no difference in mean GA at randomization but in contrast there was a difference in mean GA at delivery ( $p .04)$ between the 2 groups (the GTN group compared to placebo) [10].

In our study there was no statistically significant in prolongation of gestation by 48 hours which achieved in $42 / 50$ patients, 20 patients in group 1 (GTN) $80 \%$ as compare to 22 patients seen in group 2 (Ritodrine) $88 \%$. Also there was no significant after 7 days between the both groubs, $72 \%$ of cases continued over a week in group 1 (GTN) compare to $80 \%$ of cases in group 2 (Ritodrine).

In counter with our study RCT by Jain C et al., comparing the Glyceryl trinitrate patch versus intravenous ritodrine for tocolysis in pre-term labour they found that there was statistically not significant. Prolongation of gestation by $48 \mathrm{hrs}$ was considered successful tocolysis which was achieved in $41 / 50$ patients $(82 \%)$ combined, 22 patients $(88 \%)$ in group I (GTN) as compared to $19(76 \%)$ seen in group II (IV Ritodrine). $p$-value -0.23 showed no statistical significance. $88 \%$ patients had pregnancy prolongation by 48 hours, $72 \%$ over a week and $44 \%$ continued over 37 weeks in GTN group compared to $76 \%, 54 \%$, and $20 \%$ in Ritodrine group [8].
In Wani et al., study on 403 women, 132 were randomly assigned to receive GTN (ns67) or ritodrine (ns65) using. The women in the two groups had similar characteristics. The GTN group was more likely than the ritodrine group to deliver after 34 and 37 weeks' gestation and had fewer infants below $2500 \mathrm{~g}$ whose admission rate to neonatal intensive care was halved [11]

Also Jain et al., showed that GTN group showed higher success rate as compared to Ritodrine group (88\% versus $76 \%$ ) as opposed to study conducted by Lees $\mathrm{CC}$ et al., who showed that Ritodrine may be more effective ( $84 \%$ vs. $90 \%$ for GTN and Ritodrine). Both the Jain C et al., study and Lees $\mathrm{CC}$ et al., concluded that both drugs were equally effective in prolongation of gestation reported by Lees et al., [12]. The difference was not statistically significant.

Nankali et al., showed that the average prolongation of the pregnancy in the GTN group ranged from 9.5 days in the study conducted by Bisits on PROM and fibronectin positive women [13] to 20.9 days [10] 34 days [14] and 42 days [12] in studies where their inclusion criterion was uterine contractions.

In the current study as regard maternal outcome and side effect we found that when compare the 2 studied group it was found MHR after treatment was significant higher in group 1 than group 2 . When compare the 2 studied group it was found there was no significant statistical difference between two studied groups as regard Mean Arterial Pressure (MAP).

In agree with our study Nankali et al., showed that regarding incidence of complications, despite minor differences in the drug and placebo groups, only headache had a statistically significant difference. In the GTN group, Systolic Blood Pressure (SBP) and mean arterial blood pressure (MAP) showed a significant drop after the use of medication. Moreover, the Maternal Heart Rate (MHR) indicated a significant increase. Moreover, the differences were compared between the mean values measured before and after use of patch in the drug and placebo groups. There was a significant difference between the mean systolic blood pressure, mean arterial blood pressure and maternal heart rate in the drug and placebo groups [15].

In our study when compare the 2 studied group it was found that group 1 showed significantly higher percentage of cases suffering from palpitation, tachycardia and chest pain than group 2. But 
group 2 showed significantly higher percentage of cases suffering from headache than group 1 .

In agree with us conde-agudelo et al., revealed that treatment with transdermal nitroglycerin was associated with a significant decrease in the rates of maternal tachycardia, flushing, palpitations, nausea/vomiting, chest pain, dyspnea, discontinuation of treatment because of adverse events and fetal tachycardia, and a significant increase in the rates of headache and hypotension [16]

As regard to Jain et al., they showed that among studied patients $7(28 \%)$ patients had headache relieved with simple analgesics and few patients had cutaneous reaction in the form of erythematous rash and burning sensation in GTN group. Comparatively the Ritodrine group had severe adverse effects requiring discontinuation of therapy in $8 \%$. Tachycardia $>110 \mathrm{~min}$ was seen in $60 \%$ of cases, palpitations in $20 \%$, nausea and vomiting in $24 \%$ and dizziness in $8 \%$ but serious adverse effects like pulmonary edema and hypotension was not observed [8]

In agree with us Rowlands et al., [17], Lees et al., [12] reported $3.12 \%$ and $3 \%$ cases complaining of giddiness and Lees et al., reported $7.69 \%$ patients developing hypotension for which the patch had to be removed. Ritodrine, a nonselective, beta adrenergic receptor stimulator may act on beta receptors of the heart thus producing significant maternal adverse effects like tachycardia, atrial flutter, insufficiencies, arrhythmias and ischemia [18].

In the current study as regard fetal outcome and fetal side effect we found that when compare the 2 studied group it was found FHR after treatment was significant higher in group 1 over course of treatment than group 2. Group (1): There was $7(28 \%)$ fetus suffered from respiratory distress and $7(28 \%)$ cases needed Intensive Care Unit (ICU).

Group (2): There was 5 (20\%) fetus suffered from respiratory distress and $5(20 \%)$ cases needed Intensive Care Unit (ICU). when compare the 2 studied group it was found there was no statistical significant differences between the two studied groups, when compare the 2 studied group it was found there was no statistical significant differences as regard fetal weight between the two studied groups. $p$-value $=0.109$.

In a agreement with our result Conde-agudelo et al., meta analysis showed that there were no significant differences between the groups in the risk of neonatal morbidity, although a significant reduction was seen in the risk of admission to NICU and use of mechanical in the transdermal nitroglycerin group compared with the 132 adrenergic-receptor agonists group [18] .

Another study by Jain et al., revealed that no case of fetal distress was detected in in GTN Group as compared to $4(16 \%)$ in Ritodrine. There was no case of intra uterine death or Stillbirth in either groups. Birth weight in GTN group was found to be better with 10 neonates having birth weight $>2.5 \mathrm{~kg}$ as compared to only 2 in Ritodrine group. Mean birth weight was higher in GTN group (2.36 $\mathrm{kg}$ versus $2.05 \mathrm{~kg}$ ) as compared to Ritodrine group [8].

\section{Conclusion:}

Both glyceryltrinitrate and ritodrine were comparable in prolongation of gestation in patients in preterm labour, both in duration and in terms of success. The advantages of glyceryltrinitrate patch over ritodrine are lesser side effects and simplicity of administration and it also allows the patient to remain ambulatory.

\section{References}

1- JUNEJO N., MUMTAZ F. and UNAR B.A.: Comparasion of salbutomol and nefidepine as a tocolytic agent in the treatment of preterm labour. J. Liaquat. Uni. Med. Health Sci., 7: 115-9, 2008.

2- GHAZI A., JABBAR S. and SIDDIQ N.M.: Preterm Labour still a challenge. Pak. J. Surj., 22: 222-6, 2006.

3- BENNETE P. PRETERM LABOUR. In: EDMOND D.K., editors. Dewhursts Text book of obstetrics and gynecology. 7th ed. Blackwell Publishing Ltd, 21: 117-91, 2007.

4- AARON B. CAUGHEY, M.P.H., JULIAN N. ROBINSON and ERROL R. NORWITZ: Contemporary Diagnosis and Management of Preterm Premature Rupture of Membranes. Rev. Obstet. Gynecol., Winter, 1 (1): 11-22, 2008.

5- GOLDENBERG R.L.: The management of preterm labour. Obstet. Gynecol., 100: 1020-37, 2002.

6- BARDEN T.P., PETER J.B. and MERKATZ I.R.: Ritodrine Hydrochloride: A Betamimetic agent for use in preterm labour. Obstet. Gynecol., 56 (1): 1-7, 1980.

7- SMITH G.N., WALKER M.C., OHLSSON A., O'BRIEN K. and WINDRIM R.: Randomized double-blind placebocontrolled trial of transdermal nitroglycerine for preterm labour. A.J.O.G., 196: 37.e1-37.e8, 2007.

8- JAIN C., SINHA M., RANI R., et al.: Glyceryl trinitrate patch versus intravenous ritodrine for tocolysis in preterm labour. Int. J. Reprod. Contracept. Obstet. Gynecol., Dec., 5 (12): 4447-52, 2016.

9- SINGH N., DUBEY P., GUPTA N., et al.: Comparative study of various tocolytics in preterm labour. Int. J. Reprod. Contracept. Obstet. Gynecol., 4: 334-7, 2015. 
10- SMITH G.N., WALKER M.C., OHLSSON A., et al. Randomized double-blind placebo controlled trial of transdermal nitroglycerin for preterm labor. Am. J. Obstet. Gynecol., 196 (1): 37, 2007.

11- WANI M.P., BARAKZAI N. and GRAHAM I.: Glyceryl trinitrate vs. ritodrine for the treatment of preterm labor. International Journal of Gynecology and Obstetrics, 85: 165-, 2004.

12- LEES C.C., LOJACONO A., THOMPSON C., et al.: Glyceryl Trinitrate and Ritodrine in Tocolysis An International Multicenter Randomized Study, 94 (3): 403-8, 1999.

13- IAMS J.D., CEBRIK D., LYNCH C., et al.: The rate of cervical change and the phenotype of spontaneous preterm birth. Am. J. Obstet. Gynecol., 205.130.e1-130.e6, 2011.

14- LEES C., CAMPBELL S., JAUNIAUX E., et al.: Arrest of preterm labour and prolongation of gestation with glyceryl trinitrate, a nitric oxide donor. Lancet, 343 (8909): 1325-6, 1994

15- NANKALI A., JAMSHIDI P.K. and REZAEI M.: The Effects of Glyceryl Trinitrate Patch on the Treatment of Preterm Labor: A Single-blind Randomized Clinical Trial. J. Reprod. Infertil., 15 (2): 71-7, 2014.

16- CONDE-AGUDELO A. and ROMERO R.: Transdermal Nitroglycerin For The Treatment of Preterm Labor: A Systematic Review and Metaanalysis. Am. J. Obstet. Gynecol., December; 209 (6): 551.e1-551.e18, 2013.

17- ROWLANDS S., TRUDINGER B. and VISVA-LINGAM S.: Treatment of preterm cervical dilatation with glyceryl trinitrate, a nitric oxide donor. Aust. N. Z. J. Obstet. Gynaecol., 36: 377-81, 1996.

18- DOLLERY C.: Ritodrine (hydrochloride). In: Therapeutic drugs. edn. Vol. 2, Edinburgh: Churchill Livingstone, pp. R47-R49, 1999a.

\section{دراسة مقارنة بين فعالية ريتودرين هيدروكلوريد مقابل التصحيح النتروجلسرين بإعتباره حل المخداض قيل قصير الأجل}

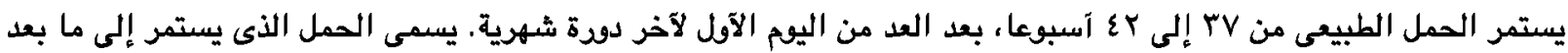

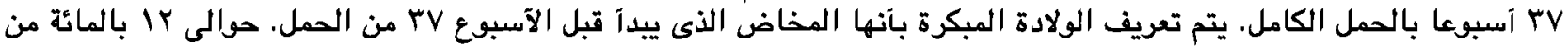

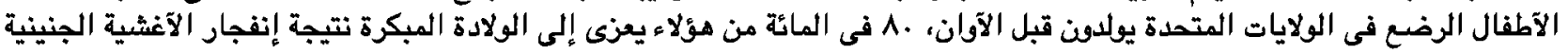

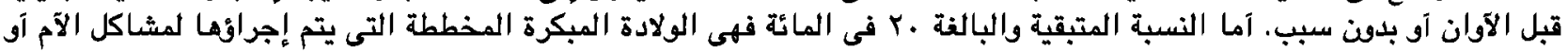

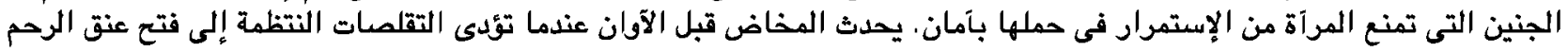

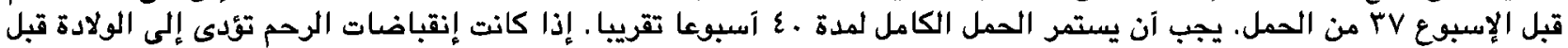

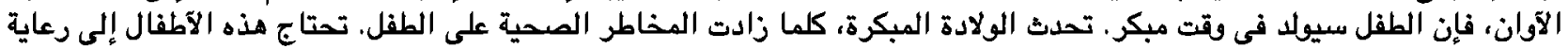

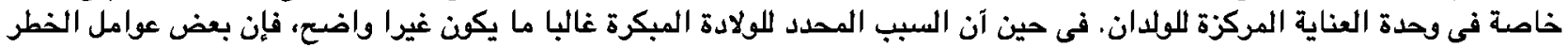

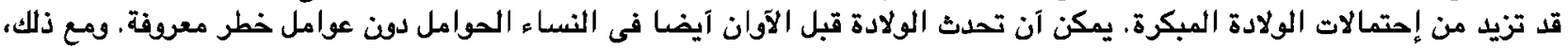

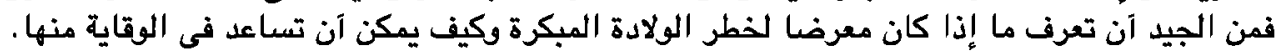

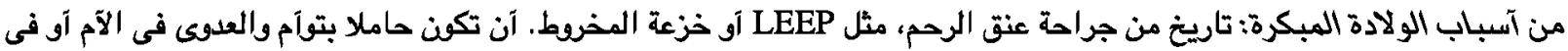

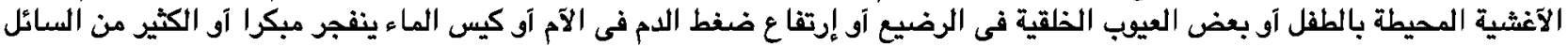
الآمينوسى آو الثلث الأول من النزيف.

معايير الإستبعاد : مشاكل بالجنين: تشوهات الآجنة أو تآخر فى نمو الجنين آو إضطراب فى الوظائف الحيوية لجنين.

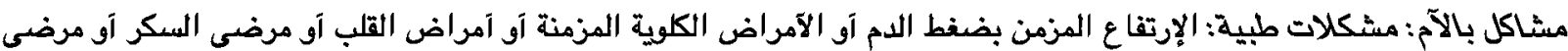

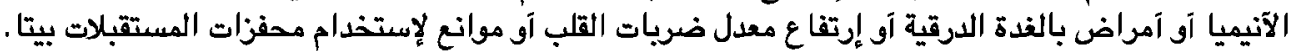

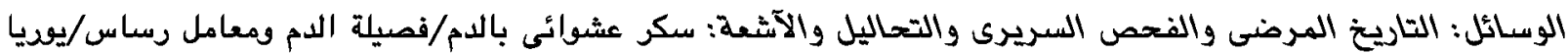

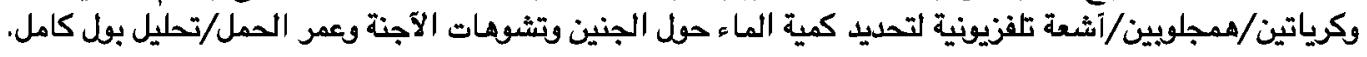

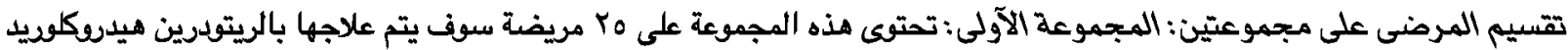

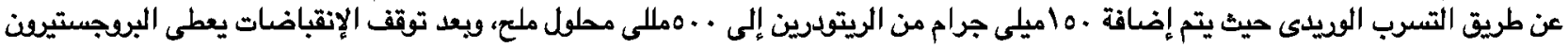
المهبلى.

المجموعة الثانية: تحتوى هذه المجموعة على To مريضة يتم علاجها بواسطة لاصقة النيتروجلسرين بتركيز ـ الملى جرام حيث يتم وضعها

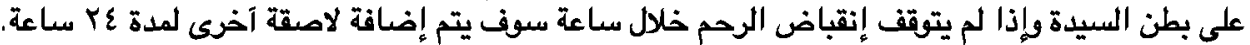

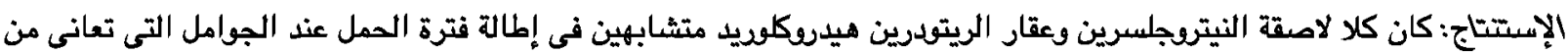

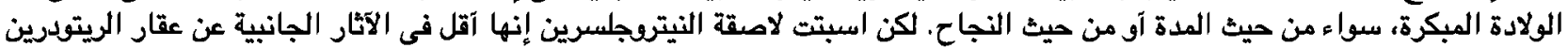

